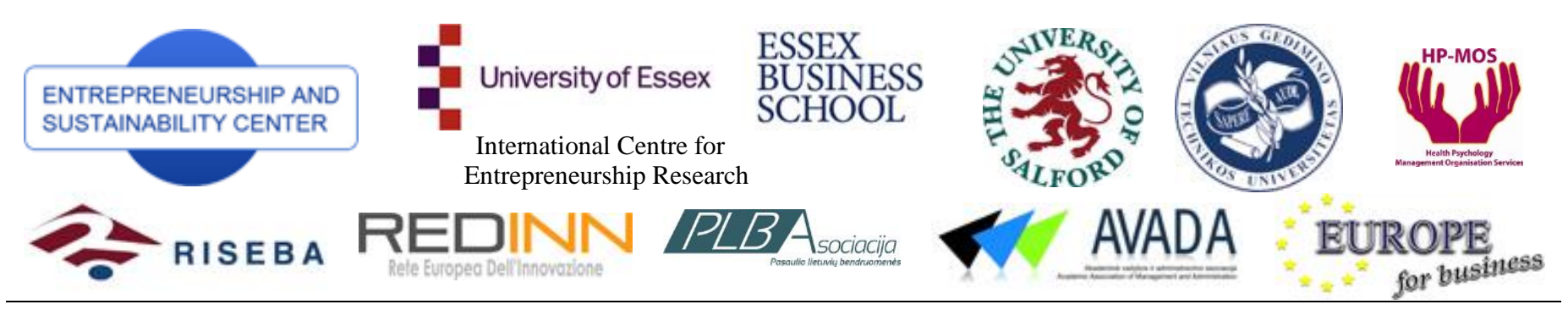

ENTREPRENEURSHIP AND SUSTAINABILITY ISSUES

ISSN 2345-0282 (online) http://jssidoi.org/jesi/aims-and-scope-of-research/

\title{
SUSTAINABLE ENTREPRENEURSHIP THROUGH ENERGY STEWARDSHIP: ROLE OF VALUES AND BEHAVIORAL PATTERNS
}

\author{
Jurgita Raudeliūniené $\dot{1}^{1}$ Manuela Tvaronavičiené², Ignas Dzemyda ${ }^{3}$, Mohamad Sepehri ${ }^{4}$ \\ 1,2,3 Vilnius Gediminas Technical University, Saulètekio av. 11, LT-10223, Vilnius, Lithuania \\ ${ }^{4}$ Jacksonville University, 2800 University Boulevard North, Jacksonville, FL 3221, USA \\ E-mails: ${ }^{1}$ jurgita.raudeliuniene@vgtu.lt; ${ }^{2}$ manuela.tvaronaviciene@vgtu.lt; ${ }^{3}$ ignas.dzemyda@vgtu.lt, ${ }^{4}$ msephr@ju.edu
}

Received 15 October 2014; accepted 21 November 2014

\begin{abstract}
In conditions of globalization, due the transformation of the information society to the knowledge society, changing technological and social circumstances, change not only the needs of consumers, but also can be observed structural changes in the management structure, economics and management science disciplines. Especially actual for business practitioners and researchers discourse becomes sustainable entrepreneurship through energy stewardship concept, which is associated with the ability to discover new opportunities for creation of economic and social value for consumers and the organization, country, region and the world. Under such circumstances it is important to identify the key factors of sustainable entrepreneurial through energy stewardship, because it is becoming one of the cornerstones of strategy of Europe in order to become the most competitive economy in the world. Scientists investigating the concept of sustainable entrepreneurship through energy stewardship and its components expose to the problem, which is more integrated approach that reflects the reality. The goal of article is to present the concept of sustainable entrepreneurship through energy stewardship and identify key success factors for sustainable entrepreneurship through energy stewardship in the global economy.
\end{abstract}

Keywords: sustainable entrepreneurship, energy stewardship, behavioral patterns, global economy, values

Reference to this paper should be made as follows: Raudeliūnienė, J.; Tvaronavičienè, M.; Dzemyda, I.; Sepehri, M. 2014. Sustainable entrepreneurship through energy stewardship: role of values and behavioral patterns, Entrepreneurship and Sustainability Issues 2(2): $107-117$.

DOI: http://dx.doi.org/10.9770/jesi.2014.2.2(6)

JEL Classifications: M10, Q01, Q43, F64

\section{Introduction}

Structural economic changes has led to a stage of sustainable development, where major economic success factors appeared to be entrepreneurship (Laužikas, Mokšeckienė 2013; Moskvina 2013; Bonetto et al. 2014), knowledge (Figurska 2014; Tvaronavičienè et al. 2014), application of technology (Išoraitė 2014), innovations and energy stewardship (Kaminskienè et al. 2014; Tvaronavičienè 2014; Tvaronavičiené et al. 2014; Vasiliūnaite 2014). As globalization increasingly influences business competitiveness through energy stewardship and operational area, organization faces problems not only of the ability to adapt to global economic trends, as well as issues of technology transfer and application, but also how to change consumer behaviour aspects. In order to achieve sustainable entrepreneurship through energy efficiency enhancing, we need to rely on such factors as new culture, values and behavioural patterns. It is important to focus on cultural change and acceptable behavioral patterns for finding more efficient ways of energy use. In this context sustainable entrepreneurship transforms into a key factor of efficient energy resources use through instilling new approaches 
towards energy consumption. The concept of sustainability entrepreneurship is a relatively new concept in scientific literature. The concept is developed aiming to relate sustainable development and entrepreneurship literature (Hall et al. 2010; Vasiliūnaite 2014). In this theoretical perspective sustainable entrepreneurship could be defined as a synthesis of conventional and social entrepreneurship. Sustainable entrepreneurship could be defined as the process of identifying and starting a new business venture, organizing and managing needed resources, thinking both risks and revenues related with the venture, while considering of how, by whom, and with what economic, psychological, social, and environmental consequences, the opportunities are discovered, created, and exploited to bring future goods and services into existence (Dzemyda, Raudeliūnienė 2014).

Sustainable entrepreneurship is a concept related to ability to find new opportunities, ability to realise and create economic, ecological and social value, take into account contemporary sustainability and security issues, especially related to energy security (Lankauskienė, Tvaronavičienė 2012; Tvaronavičienè 2012; Miškinis et al. 2013; Vosylius et al. 2013; Baublys et al. 2014; Balitskiy et al. 2014; Garškaitė-Milvydienė 2014; Matyasik 2014; Scaringelli 2014; Vasiliūnaite 2014). A key factor of successful development of the country or region is becoming knowledge and innovation based on sustainable entrepreneurship through energy stewardship. It is important to present new ways how to create sustainable entrepreneurship through energy efficiency that is directly related with operational efficiency, cultural aspects, and economic efficiency and environment sustainability.

The goal of article is to present the concept of sustainable entrepreneurship through energy stewardship and identify key success factors for sustainable entrepreneurship through energy stewardship in the global economy.

\section{Sustainable entrepreneurship through energy stewardship}

The discussion about sustainable development arose from the account of vast ecological, economic and social problems: most of these problems resulted from the proliferation of the current system of production and consumption from local to the global scale (Zabel 2005; Vasiliūnaite 2014). In order to describe the concept of sustainable entrepreneurship through energy stewardship at the beginning is necessary to define the concept of entrepreneurship, which is dealt with in different scientific fields: economics, psychology, management, education science.

Throne-Holst, Strandbakken, Eivind (2008) based on former studies, six potential barriers for radical consumer changes were identified: physical and structural barriers; political barriers; cultural-normative barriers; economic barriers; information barriers; and individual-psychological barriers. The following three are considered as those with the highest explanatory value:

- cultural (realising optimal adjustments between work- and family life, hobbies and interest, and in addition an extensive social life is viewed positively; the degree of freedom is also limited by other cultural norms: in the sense that the range of options for energy savings are constrained by behavioural norms and rules in different settings);

- economic (there are economic barriers to investments in new energy systems, and this is confirmed by the recent public debate on this matter);

- information (the consumers not only need information on what and how to save energy, but also help in identifying when they should make their investments).

According Bunse et al. (2011), there are three main drivers that forces industries to put in efforts to increase energy efficiency: the increase of energy prices, the introduction of new environmental regulations, and consumers purchasing behaviour (Bunse et al. 2011). According to Hussaini, Majid (2014), energy use have revealed three major issues that are associated with energy efficiency as: architectural (design) issue, appliances/services (technology) efficiency issue, and the human (behavioural) issue. Nonetheless, there is a fundamental assumption that the technology-based improvement on energy efficiency is significantly influenced by human social behaviour in the utilization of the energy. According Authors, the human dimension to energy analysis is influenced by the level of education, awareness and social status of the individual users of the energy (Hussaini, Majid 2014). 
Entrepreneurship is percieved today as a cultural and economic phenomenon. Entrepreneurship could be understood as activities of creation of new businesses that produce new products and services, and thereby ensure public needs, such as to create new jobs and contribute to the overall economic stimulus and developement of community life quality. Entrepreneurship is very important for economic development, believing that people in developing countries have a lot of potential to create, develop and manage their own businesses, thereby contributing to a variety of social problems such as sustainable regional development, solving problems of unemployment in general, the involvement in solving issues of povety.

From the social and economic perspectives of the business, entrepreneursip is understood as the ability to achieve results in organization. In psychological sciences entrepreneurship is regarded as an individual personal characteristics, traits, abilities in acting organization's success. From the science of management pint of view entrepreneurship is interpreted as an element of strategic management, seeking to link aims of organization and personal intentions. Of education positions enterpreneurship is examined through entrepreneurship education and innovation development perspective.

Vinig and de Kluijver (2007) refer to the conditions of modern entrepreneurship to be considered in light of the growing importance and influence of the phenomenon of globalization. Therefore, the authors perceive entrepreneurship as a three-dimensional interface, including the ability to discover new opportunities; the ability to deploy and use existing resources to exploit discovered opportunities; participation in a global society and preparation for global competition. L. Galloway (2009) argues that the concept of entrepreneurship can fully understood just in case it will explore how the relationship between personality characteristics and personal knowledge and practical skills with a whole based on appropriate attitudes and learning.

Entrepreneurship is defined by characteristics of a person, values, skills, attitudes provisions own business building intentions in the context of activating, distinguishing between the internal and external determinants of entrepreneurship. Internal determinans are related with individual entrepreneurship curriculum, educational intervention aimed to influence individual entrepreneurial internal factors (attributes values, skills, perceptions, and behavior). External determinant are understood as other then personal entrepreneurial factors (social, economic, political, legal) acts personal point of view of intrapreneurship within an institutional framework for entrepreneurship education. These few examples of the entrepreneurial concept definitions show that different authors emphasize different aspects of entrepreneurship. With the rapid emergence of scholarly thinking and analysis about entrepreneurship has come a multiplicity of approaches, emanating from different academic traditions, that has resulted in an academic field that is complex and heterogeneous with respect to approaches, methodologies and even the understanding about what exactly constitutes entrepreneurship (Audretsch 2012).

Sustainablility entrepreneurship is more complex issue. Sustainablity entrepreneurship can be understood as enterpreneurs activities that meet the needs of the present without compromising the ability of future generations to meet their own needs. The strong relationshis between entrepreneurship and sustainable development exist in research literature literature. There are used such concepts as environmentally orientated entrepreneurship; social entrepreneurship (entrepreneurship that aims to provide innovative solutions to unsolved social problems); institutional entrepreneurship (contributing to change regulatory, societal and market institutions), responsible entrepreneurship (a term coined which joining economic, technological, environmental factors is or must be responsible to society, enhancing the business positive contribution to society whilst minimizing negative impacts on people and the environment) (Kardos 2012).

The concept of sustainable entrepreneurship (or sustainability entrepreneurship) can be defined by differently. Sustainable entrepreneurship is an area within the larger concept of sustainable development (Parra 2013). Sustainable entrepreneurship can be understood as the examination of how, by whom, and with what economic, psychological, social, and environmental consequences the opportunities are discovered, created, and exploited to bring future goods and services into existence (Cohen and Winn 2007, p. 35). From the process scope, it is the process of discovering, evaluating, and exploiting the economic opportunities present in market failures which detract from sustainability, including those that are environmentally relevant (Dean and McMullen 2007, p. 58). 
As well sustainable entrepreneurship is defined as the teleological process aimed at the achievement of sustainable development by discovering, evaluating and exploiting opportunities and creating values that produce economic prosperity, social cohesion and environmental protection (Katsikis and Kyrgidou 2008, p. 2).

According to Lans et al. (2014), the concept of sustainable entrepreneurship has gained importance over recent years. The relationship between entrepreneurship and sustainable development has been dealt with through various schools of thought, often resulting in the launching of new types of entrepreneurs, such as the ecopreneur and the social entrepreneur. The concept of 'sustainable entrepreneurship' has been coined more recently as an overarching way of looking at the contribution of entrepreneurial endeavours to social, ecological and economic aspects: or, in other words, sustainable development (Lans et al. 2014). Santiago (2013) represents, that even if the concept of sustainability entrepreneurship is unknown to the entrepreneurs, yet, they engaged in sustainable business practices, meant to improve living conditions of marginalized groups. However, while they have actually helped communities to take better control of their livelihood, they have not yet consciously imbibed the element of futurity (Santiago 2013).

Sustainable entrepreneurship is much related with energy stewardship. Sustainable entrepreneurship is much related with strategy based on conscious use of energy, as well as using renewable energy sources. This makes a lot of chalanges. Because renewable energy sources are stochastic and geographically diffuse, their ability to match demand is determined by adoption of one of two approaches: the utilisation of a capture area greater than that occupied by the community to be supplied; or the reduction of the community's energy demands to a level commensurate with the locally-available renewable resources (Omer 2012).

The potential energy savings is one of the most important determinant of sustainable business. This could be achieved by basing sustainable entrepreneurship on renewable energy technologies and green energy. The key factors to reducing and controlling $\mathrm{CO} 2$, which is the major contributor to global warming, are the use of alternative approaches to energy generation and the exploration of how these alternatives are used today and may be used in the future as green energy sources (Omer 2012). This aspect is much related with energy relations and energy consumtion quantifications that opens new ways of the energy security and sustainable competition. This is potentially of considerable interest given that energy security is a widespread concern, particularly among highly energy dependent and vulnerable countries, and in view of the current context of growing competition for resources, characterised by increasing energy demand and the exhaustion of fossil fuels (Munoz-Delgado 2011). Thus, according Ozolina, Roša (2013) research results, is a lack of information regarding costumers' role and impact on energy efficiency in general.

Bonzo (2008) points out, the most important role of energy policy is its contribution towards achieving sustainability in the social, economic and environmental dimensions of development. In order to achieve energy sustainablility, it is important that authorities elaborate a long-term energy plan that envisages a sustainable development path (Fellows 2006). At some stage, we need to move from the relativism of improvement to the absolutism of sustainability assurance, if only, to the best that our knowledge allows - only such a stance is really a culture of sustainability (Fellows 2006). 


\section{Personal benefits}

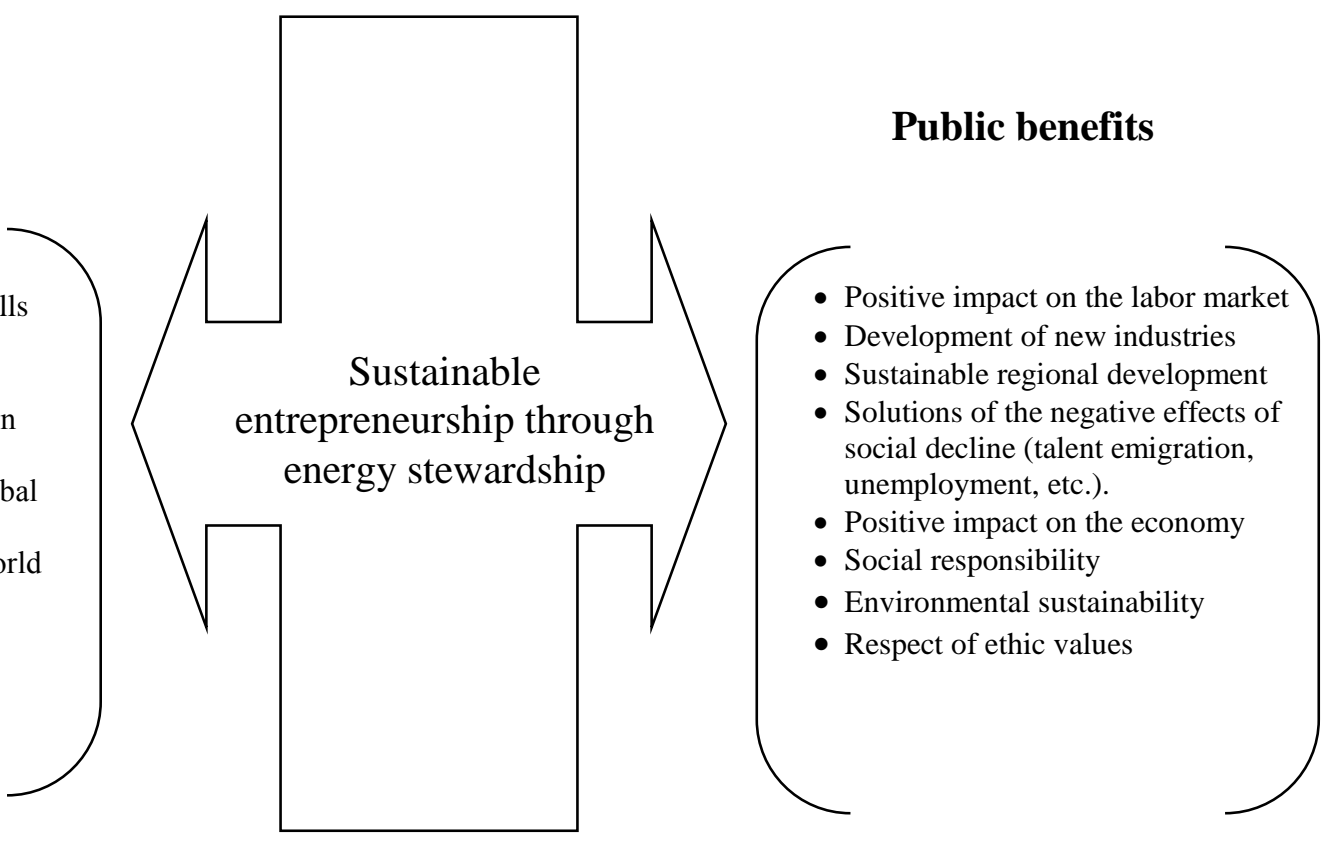

Fig. 1. Sustainable Entrepreneurship through Energy Stewardship

An analysis conducted by Martinez (2010) indicated that economic and technical factors have played an important role in the energy efficiency performance because increases in economic growth and technology improvements increase the industrial sector's ability to improve energy efficiency. Abdelhamid et al. (2011) shows that this new technology represents in theory a solution for environmental problems and could also be economically competitive with conventional energies if wisely exploited.

In sum, the promotion of sustainable entrepreneurship has a positive impact on both the individual level and the social level, as well as for energy security. One of the most important ways to achieve sustainable entrepreneurship is through energy stewardship. The concept of sustainable entrepreneurship through energy security is presented in Figure 1.

In conclusion, sustainable entrepreneurship ithrough energy security is very much affected by changed needs and behavior of consumers. We can identify shift from need of cheap goods and services of mass production to niche products and services delivered on sustainable way. By reached good life quality consumers start to consider options to consume less, but better quality products and services, produced on conscious way. This makes the social change of values of consumers. Sustainability of the product is as much important as other more material aspects, such as durability and functionality of products. Sustainable entrepreneurship could be implementend in societies, taking into account not only benefits that they get from the product, but as well as other more sophisticated values, related with public benefits in the terms of socio-economic, environmental, respect of ethical values (like fair trade supply chain, animal rights, support of local production). By this change of consumption entrepreneurs are encouraged to balance their personal benefits with public benefits, and to orientate their entrepreneur activities to more sustainable way.

\section{Key success factors of sustainable entrepreneurship: role of values and behaviour patterns}

Changes in consumtion in conditions of globalization has significant impacts on sustainable entrepreneurship the rapid development of technology, hyper-competition, constant change, information surplus, more sophisticated concumer behavour, etc. This socio-economic change provides both new opportunities and new challenges. Under these conditions sustainable entrepreneurship through energy stewardship becomes a very 
important determinant for local economies to response global chalanges. Because of this it is a very important to identify key success factors of sustainable entrepreneurship.

Key success factors of sustainable entrepreneurship is in much part related with culture or organization. Seemingly, at present, that requires a cultural shift from immediate self-interest perspectives which are commonplace; as such, institutions are likely to be forced to act as catalytic instruments (as in safety) to initiate change through pluralist mechanisms of various levels of formality and appeal (Fellows 2006). Interpretation of what represents entrepreneurship is likely to vary cross-nationally according to the distinctive patterning of social values and norms of behaviour rooted in the host culture (Omar and Davison 2001). Culture represents a complex and largely ethereal phenomenon, compounded by its multiple representation within such elements as: different levels (national, regional, business, individual); layers of society (gender, age, social class, occupation, family, religion); and varying context of life (individual, group, community) (Morrison 2006). If it is a culture, it espouses our values and shapes our behaviour such that sustainability is the norm, rather than the exception (Fellows 2006).

Zabel (2005) was suggested a model of human behaviour for sustainability, which try to establish new structures to enhance sustainable behaviour on the individual level. These efforts aim at constructing a network of interaction among institutions and individuals that commit to the general ideas of sustainable development and the advancement of sustainable patterns of individual and collective behaviour. This network may provide a chance to have some bearing on individual behaviour through cultural and situational influences. Adequate framework conditions at the local, regional, national and international level are necessary to change values and individual behaviour. According Zabel (2005) the establishment of a sustainability-oriented interaction network will only succeed if the relevant social and individual actors contribute. Fields of action are: legal regulation, education, infrastructure, and support for cultural activities, nature conservation, public participation and deliberation, prevention of risks, open access to information and others (Zabel 2005).

According Ozolina, Roša (2013) research results, there are at least three elements that can influence energy efficiency progress in manufacturing companies: energy prices, environmental regulations, consumers. The major difference is that the consumers' behaviour cannot be regulated directly by state policy. The opposite way is through environmental regulations. The state can be the initiator to develop new regulations in order to promote energy efficiency in companies. A smaller impact of the state can be seen in the regulation of energy prices, but still the energy prices depend on the market conditions, general state policies and strategies. It is very hard to influence consumers because there are different factors that are taken into account before choosing the products. Also, the factors related to environmental issues are less important.

For changing customers behavioral aspects, Hussaini, Majid (2014) suggesting to use a social scheme of balanced framework like the "TIME" model: targeting (this is to recognize the consumption pattern; and the diversity within the community in terms of people and their actions); informing/engaging (effort should be geared towards helping people and communities to develop the capacity to be mindful of their energy use through a "people-centered-initiative"; the public are encouraged to participate actively or passively in saving energy through the application of their knowledge to given situations); motivating (there is the need to motivate people using financial and non-financial mechanisms to turn intentions into behaviour through goals, norms, networks, commitments, etc.; this can be accomplished through financial incentives; use of demonstration projects to illustrate energy saving criterion); empowering/enabling (there should be concerted effort to remove financial and structural barriers; and to provide better choice sets, and creating supportive communities through policies and legislation, etc) (Hussaini, Majid 2014).

Laestidus (2003) represents, that the one of key success factor of eco-efficient business is a situation in the value chain where all actors involved show materials data for each stage that follows the product as an aggregated information package along the value. Laestidus (2003) concludes, the efficiency of becoming eco-efficient would be much more cost efficient if looking at total costs for an entire value chain, but is probably immensely difficult to implement if not supported by international legislation or at least an unofficial standard for materials declaration (perhaps followed by an international standard). Fellows (2006) concludes, that unfortunatelly, 
unless the green approach is adopted universally and very rapidly, via continuous improvement in respect of the operation of the various "environmental protection standards", it may well prove to be the case that the sustainability sought by adherents to the Brundtland principles (economic growth, environmental protection, social equality) is unattainable.

Another factor important for sustainabile entrepreneurship is promotion of this kind of business. Informing entrepreneurs of the value of sustainability entrepreneurship, may lead to more for-profit enterprises to consider the effects of their business practices on the future of marginalized group and the environment (Santiago 2013). Vinig and de Kluijver (2007) state that entrepreneurship is influenced by different aspects of globalization. The authors distinguish three main forms of globalization that affect entrepreneurship:

1. economic globalization - many companies and organizations, and business ideas coming out in several countries; is created and developed in international relations global business;

2. political globalization - is being developed by international standards and national policy, is influenced by global events. All of this has an impact on the business sector, youth entrepreneurship;

3. social globalization - which gets more opportunities, including young people, to exchange ideas and information with people all over the world, to communicate with people in different countries. This particularly facilitates information technology, various youth exchange programs and etc.

This indicates that social entrepreneurship is influenced by the conditions of globalization processes. These conditions create additional opportunities for people from developing countries, makes circumstances to gain global importance in everyday business conditions. This empowers people to act independently of increased competition. In this aspect sustainable entrepreneurship is much related with energy security as sustainability values have positive impact for energy efficiency over wide geographical areas.

Key success factors of sustainable entrepreneurship is consisted by four dimensions - sustainability, that practically could be implemented by wise use of natural resources, territorial approach of business, local business running, sustainability-driven understanding in all business processes; niche strategy; entrepreneurship and sustainable development competences (such as systems-thinking competence, embracing diversity and interdisciplinarity, foresight-thinking competence, normative competence, action competence, interpersonal competence, strategic management); ability to resist market pressure by value based business management and marketing (Raudeliūnienè et al. 2014). The key ingredient of these success factors is motivation of entrepreneur that could be increased by various political measures aiming to rise initiative of people to run existing or start new business ventures in more sustainable way (Raudeliūnienè et. al. 2014).

Howevew, the final consumer has the exclusive right to define what constitutes value in a product or service (Macharia et al. 2013). Rokeach (1973) defined value as an enduring belief that a specific mode of conduct or endstate of existence is personally or socially preferable to an opposite mode of conduct or end-state of existence. Combining values with demographic information can provide a better understanding of targeted consumers, and marketing programs based on this understanding can enhance the effectiveness of retail management (Erdem et al. 1999).

Macharia et al. (2013) researched, a consumer-focused approach to performance improvement in supply chains can lead to more satisfied consumers and improved returns to growers and retailers under increasing pressures of globalization and urbanization. The researchers identified, that Ethics Crusaders form the largest segment. The universal value profile for this segment can be summarized as: a large segment of consumers, with high preference for customer service and average preference for product quality, who mostly buy fresh vegetables from street vendors and are mainly youthful with high education but low to medium income (Macharia et al. 2013).

Another example of research of values and behavour patterns is research done by Peattie et al. (2009) on climate change on a social and commercial marketing communication. Researches finds, that effective communication on climate change which is capable of motivating changes in consumer behaviour (rather than simply raising awareness further) will depend upon: the relevance of climate change to consumers' lives and the relationship to 
their consumption behaviours being made clear; targeting strategies which take account of differences amongst key consumer segments; and developing a message which motivates rather than overwhelms consumers whilst avoiding any perceptions of "greenwashing".

The most important factors that need to be triggered in order to promote social entrepreneurship are: access to working capital; access and use of the latest technology and equipment; new product development and allowing people to try out their ideas in practice by creating value added. Thus, the greatest importance to the promotion of sustainable entrepreneurship is a practical help to people with conscious point of view and set of values, as well as want and need to start entrepreneur activities. It is necessary to promote the importance of social entrepreneurship by various means, such as entrepreneurial skills development programs, business consultancy, mentorship, local, national and international support networks. But, the most important aspect is to promote change of values of society and consumtion behaviour, to make background and education on conscious consumtion, to create a need for consuming products and services that made in sustainable way, by sustainable entrepreneurship, by people aiming sustainability.

\section{Conclusions}

Sustainable entrepreneurship is a set of conscious decisions leading success of small and medium enterprises in a very complex competitive environment. Sustainable entrepreneurship could be defined as the process of identifying and starting a new business venture, organizing and managing needed resources, thinking both risks and revenues related with the venture, while considering of how, by whom, and with what economic, psychological, social, and environmental consequences the opportunities are discovered, created, and exploited to bring future goods and services into existence. Sustainablity entrepreneurship can be understood as enterpreneurs activities that meet the needs of the present without compromising the ability of future generations to meet their own needs. Sustainable entrepreneurship is related with energy stewardship, because conscious use of energy as well as using renewable energy sources can lead to competitive success in changing global environment.

Development of sustainable entrepreneurship is very much connected to change of consumption behaviour. Key success factors of sustainable entrepreneurship is related on values and consumtion patterns. The shift from needs of cheap goods and services of mass production to niche products and services based on social and environmental responsibility is a key success factor of sustainable entrepreneurship. By change of consumption needs entrepreneurs are encouraged to balance their personal benefits in terms of revenues and profits with public benefits in terms of sustainability, and to orientate their entrepreneur activities considering socialeconomic and environmental aspects, as well as energy stewardship. Also it is needed to promote change of values of society and consumtion behaviour, to make cirsumstances conscious consumtion, to create a need to consume products and services resulted by sustainable entrepreneurship.

\section{References}

Abdelhamid, L.; Bahmed, L.; Benoudjit, A. 2012. Impact of renewable energies - environmental and economic aspects: Case of an Algerian company, Management of Environmental Quality: An International Journal 23 (1): 6-22. DOI: 10.1108/14777831211191566.

Audretsch, D. 2012. Entrepreneurship research, Management Decision 50 (5): 755-764.

Balitskiy, S.; Bilan, Y.; Strielkowski, W. 2014. Energy security and economic growth in the European Union, Journal of Security and Sustainability Issues 4(2): 123-130. DOI: http://dx.doi.org/10.9770/jssi.2014.4.2(2)

Baublys, J.; Miškinis, V.; Konstantinavičiūtè, I.; Lekavičius, V. 2014. Aspirations for sustainability and global energy development trends, Journal of Security and Sustainability Issues 3(4): 17-26. DOI: http://dx.doi.org/10.9770/jssi.2014.3.4(2)

Bonetto, P.; Hoffmann, B.; Prause, G. 2014. Rise and fall of the Lyon silk cluster: a case study about entrepreneurial sustainability, Entrepreneurship and Sustainability Issues 2(1): 1-11. DOI: http://dx.doi.org/10.9770/jesi.2014.2(1)

Bozo, M. G. 2008. Energy policies in Latin America and the Caribbean and the evolution of sustainability, International Journal of Energy Sector Management 2 (1): 8-35. 
Bunse, K.; Vodicka, M.; Schonsleben, P.; Brulhart, M.; Ernst, F.O. 2011. Integrating energy efficiency performance in production management - gap analysis between industrial needs and scientific literature, Journal of Clean Production 19 (6-7): 667-679.

Cohen, B.; Winn, M. 2007. Market imperfections, opportunity and sustainable entrepreneurship, Journal of Business Venturing 22: 2949.

Dean, T.; McMullen, J. 2007. Toward a theory of sustainable entrepreneurship: Reducing environmental degradation through entrepreneurial action, Journal of Business Venturing 22: 50-76.

Dzemyda, I.; Raudeliūniené, J. 2014. Sustainable youth entrepreneurship in conditions of global economy toward energy security, Entrepreneurship and Sustainability Issues 1(4): 247-256. DOI: 10.9770/jesi.2014.1.4(7)

Erdem, O.; Oumlil, A. B.; Tuncalp, S. 1999. Consumer values and the importance of store attributes, International Journal of Retail \& Distribution Management 27 (4): 137-144. DOI: 10.1108/09590559910268435

Fellows, R. 2006. Sustainability: a matter of energy? Property Management 24(2): 116-131. DOI: 10.1108/02637470610658005.

Figurska, I. 2014. Sustainable entrepreneurship: localization, acquiring and use of knowledge sources in competitive organization, Entrepreneurship and Sustainability Issues 1(4): 210-222. DOI: http://dx.doi.org/10.9770/jesi.2014.1.4(3)

Galloway, L. 2009. Diversity in entrepreneurship: the role of women and ethnic minorities. Enterpreneurship and small firms. Deakins, D. \& Freel, M. (Eds.) 5th edition.

Garškaitè-Milvydienè, K. 2014. Anti-crisis management of enterprises and possibilities of overcoming their critical condition, Journal of Entrepreneurship and Sustainability Issues 1(4): 187-203. DOI: http://dx.doi.org/10.9770/jesi.2014.1.4(1)

Hall, J.; Daneke, G.; Lenox, M. 2010. Sustainable development and entrepreneurship: Past contributions and future directions, Journal of Business Venturing 25(5): 439-44.

Hussaini, I. U.; Majid, N. H. A. 2014. Human behaviour in household energy use and the implications of energy efficiency delivery, International Journal of Energy Sector Management 8(2): 230-239. DOI: 10.1108/IJESM-10-2013-0005

Išoraitė, M. 2014. ICT and entrepreneurship: social network marketing, Entrepreneurship and Sustainability Issues 2(1): 19-29. DOI: http://dx.doi.org/10.9770/jesi.2014.2.1(3)

Kaminskienè, N.; Žalėnienè, I.; Tvaronavičienė, A. 2014. Bringing sustainability into dispute resolution processes, Journal of Security and Sustainability Issues 4(1): 69-77. DOI: http://dx.doi.org/10.9770/jssi.2014.4.1(6)

Kardos, M. 2012. The Relationship between Entrepreneurship, Innovation and Sustainable Development. Research on European Union Countries. Procedia Economics and Finance: Vol. 3 (January 2012): 1030-1035. DOI: 10.1016/s2212-5671(12)00269-9

Katsikis, I.; Kyrgidou, L. 2008. The Concept of Sustainable Entrepreneurship: a Conceptual Framework and Empirical Analysis, Academy of Management Proceedings 1-6.

Laestadius, P. C. S. 2003. The efficiency of becoming eco-efficient, Management of Environmental Quality, An International Journal 14 (2): 221-241.

Lankauskienè, T.; Tvaronavičienè, M. 2012. Security and sustainable development approaches and dimensions inn the globalization context, Journal of Security and Sustainability Issues 1(4): 287-297. DOI: http://dx.doi.org/10.9770/jssi.2012.1.4(5)

Lans, T; Blok, V.; Wesselink, R. 2014. Learning apart and together: towards an integrated competence framework for sustainable entrepreneurship in higher education, Journal of Cleaner Production 62: 37-47.

Laužikas, M.; Mokšeckienė, R. 2013. The role of creativity in sustainable business, Entrepreneurship and Sustainability Issues 1(1): 1022. DOI: http://dx.doi.org/10.9770/jesi.2013.1(2)

Macharia J.; Collins R.; Sun T. 2013. Value-based consumer segmentation: the key to sustainable agri-food chains, British Food Journal 115 (9): 1313-1328. DOI: 10.1108/BFJ-09-2011-0215

Martínez, C. I. P. 2010. Analysis of energy efficiency development in the German and Colombian food industries, International Journal of Energy Sector Management 4 (1): 113-13. DOI: 10.1108/17506221011033125

Matyasik, M. 2014. Secure sustainable development: impact of social media on political and social crises, Journal of Security and Sustainability Issues 4(1): 5-16. DOI: http://dx.doi.org/10.9770/jssi.2014.4.1(1)

Miškinis, V.; Baublys, J.; Lekavičius, V.; Morkvėnas, A. 2013. New Changes in Lithuanian Energy Sector, Journal of Security andSustainability Issues 2(3): 15-28. DOI: http://dx.doi.org/10.9770/jssi.2013.2.3(2)

Morrison, A. 2006. A contextualisation of entrepreneurship, International Journal of Entrepreneurial Behaviour \& Research 12(4): 192209.

Moskvina, J. 2013. Social enterprises as a tool of social and economic policy, Entrepreneurship and Sustainability Issues 1(1): 45-54. DOI: http://dx.doi.org/10.9770/jesi.2013.1.1(5)

Muñoz-Delgado, J. 2011. Affinity and rivalry: energy relations of the EU, International Journal of Energy Sector Management 5(1): 11- 
38 .

Omar, A.; Davidson, M. 2001. Women in management: a comparative cross-cultural overview, Cross Cultural Management 8: 35-67.

Omer, A. M, 2012. Clean energies development in built environment, World Journal of Science, Technology and Sustainable Development 9(1): 45-63.

Ozolina, L.; Roša, M. 2013. The consumer's role in energy efficiency promotion in Latvian manufacturing industry, Management of Environmental Quality: An International Journal 24(3): 330-340. DOI: 10.1108/14777831311322640

Parra, S. 2013. Exploring the Incorporation of Values for Sustainable Entrepreneurship Teaching/Learning, Journal of Technilogy Management \& Innovation 8(1): 11-20.

Peattie, K.; Peattie, S.; Ponting, C. 2009. Climate change: a social and commercial marketing communications challenge, EuroMed Journal of Business 4(3): 270-286.

Raudeliūnienė, J.; Tvaronavičienė, M.; Dzemyda, I. 2014. Towards economic security and sustainability: key success factors of sustainable entrepreneurship in conditions of global economy, Journal of Security and Sustainability Issues 3(4): 71-79. DOI: 10.9770/jssi.2014.3.4(7).

Rokeach, M. 1973. The Nature of Human Values. The Free Press, New York, NY.

Santiago, A. 2013. On the road to sustainability entrepreneurship: Filipino case, World Journal of Entrepreneurship, Management and Sustainable Development 9(4): 255-271.

Scaringelli, M.A. 2014. Are the foreign controlled firms more environmentally sustainable than domestically controlled ones? Journal of Security and Sustainability Issues 4(2): 131-146 DOI: http://dx.doi.org/10.9770/jssi.2014.4.2(3)

Throne-Holst, H.; Strandbakken, P.; Eivind, S. 2008. Identification of households' barriers to energy saving solutions, Management of Environmental Quality: An International Journal 19(1): 54-66. DOI: 10.1108/14777830810840363

Tvaronavičienè, M. 2012. Contemporary perceptions of energy security: policy implications, Journal of Security and Sustainability Issues 1(4): 235-47. DOI: http://dx.doi.org/10.9770/jssi.2012.1.4(1)

Tvaronavičienè, M. 2014. If industrial sector development is sustainable: Lithuania compared to the EU, Entrepreneurship and Sustainability Issues 1(3): 134-142. DOI: http://dx.doi.org/10.9770/jesi.2014.1.3(2)

Tvaronavičienè, $\quad$ M.; $\quad$ Šimelytè, $\quad$ A., $\quad$ Lace, $\quad$ N. $\quad 2014 . \quad$ Sustainable development facets: exporting industrial sectors from inside, Journal of Security and Sustainability Issues 3(4): 37-44. DOI: http://dx.doi.org/10.9770/jssi.2014.3.4(4)

Vasiliūnaitė, R. 2014. Sustainable development: methodological approaches toward issues, Journal of Security and Sustainability Issues 3(3): 69-75. DOI: http://dx.doi.org/10.9770/jssi.2014.3.3(6)

Vinig, T.; Kluijver, J. 2007. Does Globalization Impact Entrepreneurship? Comparative Study of Country Level Indicators. Netherlands: University of Amsterdam.

Vosylius, E.; Rakutis, V.; Tvaronavičienè, M. 2013. Economic growth, sustainable development and energy security interrelation, Journal of Security and Sustainability Issues 2(3): 5-14. DOI: http://dx.doi.org/10.9770/jssi.2013.2.3(1)

Zabel, H. U. 2005. A model of human behaviour for sustainability, International Journal of Social Economics 32(8): 717-734. DOI: $10.1108 / 03068290510608228$.

Jurgita RAUDELIŪNIENĖ. Assoc. Prof. Dr. of social sciences at the Faculty of Business Management, Vilnius Gediminas Technical University; member of editorial boards of peer-reviewed international scientific journals, member of scientific projects. The author and co-author of more than 30 scientific papers. Research interests: knowledge management, formation and evaluation of competitive strategic decisions, sustainable development.

Manuela TVARONAVIČIENÉ - Dr., full professor at Vilnius Gediminas Technical University, Business Management Faculty and full professor at The General Jonas Žemaitis Military Academy of Lithuania; member of editorial boards of peer-reviewed international scientific journals, expert of the Research Council of Lithuania, head and member of scientific projects. She is alumnus of IESE Business School; raised qualifications at Harvard Business School (USA) and Cambridge University, Judge School (UK). She is author of more than 60 papers. Research interests: economic growth, sustainable development, innovations, investments, energy security, entrepreneurship.

Ignas DZEMYDA. Assoc. prof. dr. of social sciences at the Faculty of Business Management of Vilnius Gediminas TechnicalUuniversity. The author carries out research in the fields of sustainable entrepreneurship, international management and the EU regional integration. He has published number of scientific research articles on various issues of management and economy. Research 
interests: strategic management, regional development, higher education, export development, innovations, new public management, sustainable entrepreneurship.

Mohamad SEPEHRI (Dr. Mo) is the Associate Dean and Director of the Graduate Business Programs (MBA, EMBA, MSOL, and DBA) and professor of Strategic International Management at Davis College of Business, Jacksonville University. He has a unique combination of academic and business experience, with extensive background in strategic management/leadership and broad experience in international and global business operations. Dr. Sepehri has Triple-Ph.D. in Management, Higher Education Administration, and Comparative Political Economy from Indiana University, Bloomington. Dr. Sepehri has been listed in the Harvard Business Who's Who as a distinguished scholar in international business. He was inducted as AIBSE Fellow in 2014. Dr. Sepehri has over 35 years of experience in strategic planning and global competitive market analysis. He is a consultant and research analyst to business corporations.

This is an open access journal and all published articles are licensed under a

Creative Commons Attribution 4.0 International License 